\title{
Leadership, decision-making and governance in the European Union and East Asia: crisis and post-crisis
}

\author{
Ramon Pacheco Pardo
}

Published online: 19 February 2012

C) Springer-Verlag 2012

The global financial crisis of 2007-2009 shattered many ideas and beliefs regarding the international political economy, and regional and global governance. Boom and bust have not disappeared; developed countries can be hit harder than emerging and developing markets, and the G20 has become the key forum to discuss global economic issues. Even though as of 2012 economic growth has resumed in most parts of the world, the looming public debt crisis in the eurozone and the need to rebalance the global economy indicate that the post-crisis world will undoubtedly look different.

Two of the regions where the effects of the crisis have been felt strongly are the European Union (EU) and East Asia. Profound changes can be expected in these two regions as the EU struggles with its sovereign debt crisis, with austerity measures and the need for a longer term strategy of economic recovery, while East Asia reexamines its export-driven growth model and comes to terms with its growing relevance and responsibility at the global level.

The EU is one of the regions where the crisis has had a far greater impact. A sovereign debt crisis followed directly the global financial crisis, shaking up the whole eurozone. So severe was the European debt crisis that the IMF was called upon to help rescue Greece, Ireland and Portugal. Even the wisdom of one of the central pillars of the European project - a common currency, the euro adopted by 17 diverging economies, was questioned. This was perceived by some within the EU as a symptom of integration fatigue and the decline of the European social model.

In sharp contrast, East Asia appeared to emerge out of the global financial crisis stronger, as several economies staged a sharp recovery in 2010 . The recession was shorter and milder than in other regions, and economic growth resumed swiftly. But East Asia also had to deal with the twin problems of being flushed with liquidity, because of funds moving from the low-growth economies in Europe, and fears of

Guest editors-Dr Ramon Pacheco Pardo and Dr Yeo Lay Hwee

R. Pacheco Pardo $(\bowtie)$

King's College London, London, UK

e-mail: ramon.pacheco@kcl.ac.uk 
inflation. The fate of many export-oriented East Asian economies remained intricately intertwined with those of other regions. Politically, tensions are also rising because of China's alleged new assertiveness and the USA's increasing interest in the region.

Globally, the emergence of the G20 has for the first time given a pivotal position on global economic governance to China, Indonesia and South Korea, and perhaps also ASEAN. Europe continued to be prominently represented in the G20 with the EU, Germany, France, the UK and Italy as full members. Concurrently, with the sharp recovery of the East Asian economies from the global financial crisis, in contrast to the sluggish performance of the Western economies, talk of a shift of power from West to East and the emergence of an Asian century, subdued during the late 1990s, became common again. But who really are the key actors leading and benefiting from the changes and challenges brought by the crisis regionally and globally? And have views on regional leadership and regional integration in the EU and East Asia shifted?

Developments within the EU and East Asia since the onset of the global financial crisis raise several questions on the internal dynamics of each region, the responses taken by the leading economies and the regional institutions, and speculations on the future roles of the EU and East Asia in a post-crisis world. Among them, a crucial one that has yet to be analysed and critically evaluated refers to the effects of the crisis on the behaviour of the different actors leading each region's respective processes of integration. This affects not only decision-making dynamics at the regional level, but the roles that each region and different actors can play in global governance.

This Special Issue of the Asia Europe Journal comes out of the papers presented at the workshop "Leadership, Decision-making and Governance in the EU and East Asia: Crisis and Post-crisis", organized by the EU Centre in Singapore. The aims of the workshop were to analyse how the global financial crisis and subsequent eurozone sovereign debt crisis have affected leadership and decision-making in the EU and East Asia, as well as governance at the regional and global levels.

In this Special Issue, the papers are organised into two broad sections. The first section "Crises and Responses" contains papers that examine how the crisis developed and morphed, and the responses taken by the different actors - at both national and regional levels to contain the impact of the crisis. The second section contains papers that look more closely into the leadership (or non-leadership) and actions taken by key member states in the EU and East Asia such as Germany, France, China, Japan and South Korea, during the crisis, and the implications their actions have on the broader issue of regional and global governance.

The special issue begins with Ramon Pacheco Pardo's overview of the effects of the crisis in these two regions, as well as an account of how power relations have shifted both within each region and between countries and regional institutions. Pacheco Pardo argues that Germany is emerging as the stronger state in the EU, while all countries in East Asia have seen their position strengthen, no one more so than China. Meanwhile, institutions have gained vis-a-vis countries in both regions.

With his contribution, Petr Blizkovsky opens the first section of this special issue, which looks at the responses to the crisis in the EU and ASEAN. In his article, Blizkovsky compares the changes in economic governance introduced by ASEAN following the 1997-98 Asian financial crisis and those changes taken by the EU as a result of the ongoing sovereign debt crisis. Blizkovsky argues that both engaged in 
deeper integration, which in the case of the EU is taking the form of the push for a stricter regulatory framework. However, the response by ASEAN was mostly of an economic nature and did not lead to closer political integration, a key difference with the way the EU is reacting to its ongoing crisis.

Iain Begg analyzes how economic governance is evolving in the EU in response to the global financial crisis and regional sovereign debt crisis. He explains how shortcomings in the governance framework created when the euro was launched have been laid bare by the crisis. Begg outlines the reforms instituted thus far and warns that even though they are steps in the right direction, further integration of decisionmaking and implementation procedures are still needed.

In his article, Paul Gillespie offers an Irish perspective on how the EU has responded to the crisis. Being deeply affected by it, but with a relatively small say on European governance, Irish attitudes towards the EU reflect those of other member states in a similar position - a desire to retain the euro is balanced by scepticism towards the response of the EU to the crisis. These perceptions, Gillespie argues, has led Ireland to re-assess its role in EU decision-making structures while at the same time trying to strengthen intergovernmentalism.

Jikon Lai and John Ravenhill focus on East Asia's response to the global financial crisis. They argue that the crisis has helped to move forward multilateralism in East Asia, most notably through the Chiang Mai Initiative Multilateralization (CMIM). The crisis has also helped East Asian countries to obtain a greater voice at the global level, namely through the IMF and the G20. However, Lai and Ravenhill warn that regional cooperation in East Asia is still limited, so greater integration and common decision-making should not be overstated.

The contribution by Kurt Hübner opens the second section of this special issue, which focuses on how the crisis has affected the leadership of different countries at the regional and global levels, as well as their role in decision-making procedures and governance. Hübner examines the case of Germany. He is critical of Berlin's leadership throughout the crisis. While recognizing that Germany has become the de facto leader of the eurozone, if not the EU, Hübner believes that there has been a high degree of procrastination and inflexibility that has exacerbated the crisis.

Reuben Wong and Albrecht Sonntag analyze the evolution of French leadership and influence before and during the twin crises affecting the EU. While they acknowledge that Germany has become more influential at the regional level, they caution against overemphasizing the decline of France. The role of France in helping Germany lead the response to the crisis should not be underestimated. Paris still serves as a co-leader in European affairs. Furthermore, France is a producer of ideas and initiatives both at the regional and global levels. International perceptions of France as a credible leader also remain strong.

China, argues Gerald Chan, has been one of the countries to emerge stronger from the global financial crisis. Thus, Beijing's contribution to regional and global governance has become more visible. This is not only evident in formal institutions, such as the G20 or the CMIM, but also in the way China is addressing global economic imbalances. Chan believes that Beijing is helping to provide multilateral responses to the crisis. This will serve to enhance its future role in global economic governance.

Meanwhile, Japan is also seeking to become more involved in multilateral approaches to the global financial crisis, argues Julie Gilson. Nevertheless, Japan's 
response to the crisis has been affected by its bilateral relations, above all with the USA but increasingly with China as well. These relationships still hinder Japan's potential leadership. But Gilson argues that Tokyo is becoming more adept at managing its bilateral and multilateral commitments. Thus, Japan is poised to become more involved in regional decision-making processes.

Park Sunghoon traces South Korea's growing role in regional and global governance from the 1997-98 East Asian crisis to the 2007-08 global one. Whilst not overstating Seoul's contribution to both, Park explains how the South Korean government has successfully pushed new issues into the economic governance agenda, most notably "development" and "green growth". He argues that South Korea has de facto joined leadership structures and processes at the regional level, thus playing a more prominent role in East Asia.

Natasha Hamilton-Hart's article moves the special issue back to regional matters, examining the developments in regional governance as East Asia confronts the global financial crisis. She explains how the crisis has not significantly strengthened multilateralism at the regional level. ASEAN's leadership explains why this is the case. While supportive of regionalism, ASEAN prefers loose structures and non-binding agreements and statements. Thus, it has been the Asian Development Bank, rather than any country, that has been the main driver behind the CMIM and other efforts to strengthen decision-making at the regional level.

Finally, Juergen Rueland analyzes the approaches of EU member states and East Asian countries to multilateralism and global governance. He argues that "forum shopping" has become the norm. Thus, countries accept multilateralism but only after carefully selecting the institutions and initiatives which enhance their national interest. East Asia engaged in forum shopping earlier than the EU, but at present both of them practice it. This has diminished multilateralism and, consequently, the prospects for successful global governance. 